\title{
The Effect of National Drug Policy Implementation and Apparatus Work Motivation on Health Service Quality in the Government Hospitals of Gorontalo
}

\author{
Muhammad Kasim Arifin Tahir Lintje Boekoesoe Rama Hiola \\ Postgraduate Program State University of Gorontalo
}

\begin{abstract}
The research intends to investigate and analyze the effects of national drug policy implementation and apparatus work motivation on health service in the government hospitals of Gorontalo.Method used in the quantitative research was exploratory survey. Meanwhile, data collection was conducted by using questionnaires and interviews to confirm the data. Furthermore, data were analyzed by using the PLS (Partial Least Square) approach by the Smart PLS 3.1 application. Research population consisted of 383 implementers of National Drug Policy in the government hospitals of Gorontalo; while the sample consisted of 93 respondents. The findings clarified that: (1) Implementation of National Drug Policy positively and significantly affected health service quality with the effect coefficient of 0.309 . The figure confirmed that although it was significant, the effect was inadequate to improve health service quality in the government hospitals of Gorontalo, hence needed other implementation variables, (2) Implementation of National Drug Policy positively and significantly affected apparatus work motivation with the effect coefficient of 0.706 , conveying that the implementation strongly affected apparatus work motivation in the government hospitals of Gorontalo, (3) Apparatus work motivation positively and significantly affected health service quality with the effect coefficient of 0.523 , declaring that the motivation strongly affected health service quality in the government hospitals of Gorontalo, (4) Implementation of National Drug Policy mediated by apparatus work motivation positively and significantly affected health service quality with the effect coefficient of 0.615 , defining the implementation should be mediated by apparatus work motivation to affect health service quality in the government hospitals of Gorontalo, and (5) Public policy integration and apparatus work motivation and commitment created a prototype of new public policy implementation model as the HSQ-MK model.
\end{abstract}

Keywords: Policy, Motivation, Commitment, and Quality

DOI: $10.7176 /$ PPAR/9-6-07

Publication date:June $30^{\text {th }} 2019$

\section{INTRODUCTION}

Health service quality is greatly influenced by the drug service quality, as drugs are one of the components that cannot be substituted in health services. Public access to drugs, especially the essential ones, are one of the human rights that have to be fulfilled by the government. Therefore, drug provision, especially the essential ones has to be realized by both the government and health service institutions either by the government or private companies. Government shall ensure drugs to be available in a complete type and adequate number according to the needs. It shall be safe, effective, qualified, affordable, and accessible.

Government shall stipulate national drug regulations and policies, because drugs are different from other trading commodities because of imbalanced or asymmetrical information among parties related to the quality, use safety, usability, price, and specific use accuracy. Besides the trading commodity, drugs have also social functions related to human health and spirits.

Drugs are a pharmaceutical provision needed by human, especially when they are suffering from illness. Unable to be treated as ordinary needs by the economic law only, drugs have been universally admitted to have their own dimensions, i.e.:

1. Economic dimension: drugs need large investments and capital, unaccountable research, and many import contents.

2. Technological dimension: drugs are greatly equipped by high and sustainable technology findings and always require experts and developments.

3. Social human dimension: drugs are important for human health and safety.

There are several government policies to ensure increased drug access and use, namely the Law Number 36 Year 2009 on Health, Government Regulation Number 51 Year 2009 on Pharmaceutical Jobs, and Regulation of the Ministry of Health of the Republic of Indonesia Number 198/Menkes/SK/III/2006 on National Drug Policy (Kebijakan Obat Nasional, KONAS).

In addition to KONAS implementation, another factor that affects health service quality, especially pharmaceutical services is apparatus work motivation, since drug provision, easy public access to drugs, and quality of pharmaceutical services are some of the health services influenced by the apparatus work apparatus that 
is directly involved in health services provided by hospitals.

Health services in hospitals are generally operated by functional workers from various health professions working individually and independently. The variety causes the motivation factor to also determine both performances and service quality given, as explained by Siagian (2003) that motivation is one of the encouragements that makes organization members willing to show their competence to engage various activities to achieve goals and targets that have been determined. When motivation is described as a physiological process that occurs in an individual that reflects an interaction among attitudes, needs of need fulfilment, perception, and others, then understanding the process and fulfilling the needs can only create the changes, although it is still far from the expectation.

The research aims to investigate and analyze:

1. Effects of KONAS implementation on health service quality in the government hospitals of Gorontalo.

2. Effects of KONAS implementation on apparatus work motivation in the government hospitals of Gorontalo.

3. Effects of apparatus work motivation on health service quality in the government hospitals of Gorontalo.

4. Effects of KONAS implementation mediated by apparatus work motivation on health service quality in the government hospitals of Gorontalo.

5. A new prototype model about public policy implementation and apparatus work motivation to increase health service quality in government hospitals.

\section{RESEARCH METHODS}

\section{A. Research Location and Period}

The research was conducted in two government hospitals in Gorontalo that were Rumah Sakit Umum Daerah Prof. Dr. H. Aloei Saboe and Rumah Sakit Umum Daerah Otahana for ten months since January-October 2018.

\section{B. Research Methods and Design}

The research applied the quantitative design with the exploratory survey method. The method was used to identify and analyze effects of KONAS implementation and apparatus work motivation on health service quality in the government hospitals in Gorontalo, either directly or indirectly.

Research analysis was done by using PLS (Partial Least Square) assisted by the Smart PLS 3.0 software. PLS was a multivariate analysis technique, a combination between the factor analysis and path analysis. Factor analysis was used to test an instrument validity and reliability (measurement scale); while path analysis was used to test the relationship among variables.

\section{Variable Concept and Operational Definition}

\section{Variable Concept}

Arrangement of variable concept referred to previous theories and consisted of three variables, i.e. KONAS implementation as an exogenous variable with the $\xi$ symbol, apparatus work motivation as the first endogenous variable with the $\eta_{1}$ symbol, and health service quality as the second endogenous variable with the $\eta_{2}$ symbol.

\section{a. Variable of KONAS Implementation ( $)$}

Here, the variable of KONAS implementation $(\xi)$ was a concept of public policy implementation referring to the research findings of Kadji (2015) that to implement a policy, synergy among three elements or dimensions, namely mentality, system, and networking was important, so that the three elements would be studied in KONAS implementation as a government policy.

\section{b. Variable of Apparatus Work Motivation $\left(\eta_{1}\right)$}

Variable of apparatus work motivation was a concept referring to the needs theory and Abraham Maslow (1990) consisting of five types of needs that were physiological needs, safety needs, appraisal needs, esteem needs, and self-actualization needs.

\section{c. Variable of Health Service Quality $\left(\mathbf{\eta}_{2}\right)$}

Concept of health service quality used referred to the concept by Ovreveit, in Saranga (2000) and Azwar (2011) consisting of consumer or patient quality, professional quality, and management or health facility funder quality.

\section{Operational Variable Definition}

Variables used in the research were operationally defined as follows:

1. Exogenous Variable of KONAS Implementation ( $\xi$ ) consisting of sub-variables or dimensions and indicators:

a. Mentality approach $\left(\xi_{1}\right)$ : We summarized indicators of the mentality approach dimension as follows: i) attitude, i.e. a. Love, b. Honesty, c. Discipline; ii) Behavior, i.e. Ethical code understanding, b. Integrity, c. Courage to act; and iii) Accountability, i.e. Procedure accordance, b. Effective time management, drugs required in hospitals were always available, c. Readiness for any risk.

b. System approach $\left(\xi_{2}\right)$ : Dimensions and indicators of system approach were: i) Regulation system covering: a) Policy for public importance, b) Increased service productivity, c) Transparency; ii) Cultural values covering: a) Local wisdom, b) Kinship, and c) Mutual cooperation; and iii) Organization structure and function covering: a) Government interaction, b) Harmonious relationship in organization, and c) 
Maintained integrity.

c. Networking approach $\left(\xi_{3}\right)$ : Dimensions and indicators of the approach were: i) Strategic partnership including: a) Cooperation, b) Equality, c) Openness; ii) Synergy including: a) Institutional aspect, b) Policy, c) Program budgeting; and iii) Mutualism symbiosis covering: a) Mutual need, b) Mutual advantage, and c) Mutual support.

2. First Endogenous Variable of Apparatus Work Motivation ( $\eta_{1}$ ) consisting of sub-variables or dimensions and indicators:

a. Physiological needs: To observe this dimension, indicators used were: 1) Work room provision, 2) Work facility provision, and 3) Work facility provision.

b. Safety needs: To observe this dimension, indicators used were: 1) Guaranteed work environment safety, 2) Safety support to perform jobs, and 3) Protection against job risks.

c. Love needs: To observe this dimension, indicators used were: 1) Incentive, 2) Leader love, and 3) Related institution appreciation.

d. Esteem needs: To observe this dimension, indicators used were: 1) Relationship among workers, 2) Support from partners, and 3) Relationship between workers and related work unit.

e. Self-actualization needs: To observe this dimension, indicators used were: 1) Actualization of worker identity, 2) Actualization of worker professionalism, and 3) Actualization of worker accountability.

3. Second Endogenous Variable of Health Service Quality in Government Hospitals in Gorontalo consisting sub-variables or dimensions and indicators:

a. Dimension of consumer or patient quality: To observe this dimension, indicators used were: 1) Service given in accordance to patient desire, 2) Worker responsiveness, 3) Smooth communication, and 4) Hospitality.

b. Dimension of professional quality: To observe this dimension, indicators used were: 1) Service in accordance with professional diagnose, 2) Service in accordance with knowledge and technology, 3) Service in accordance with profession autonomy, and 4) Service in accordance with ethical codes and profession service standards.

c. Dimension of management quality and health service funder: To observe this dimension, indicators used were: 1) Service given without waste and errors, 2) Affordable price, 3) Efficient funding source use, and 4) Normal health funding.

D. Population and Sample

1. Population

The research population consisted of KONAS implementers in the government hospitals in Gorontalo, not all of the hospital workers. The implementers were hospital management, medical workers, pharmaceutical workers, and nursing workers that were the permanent employees or civil servants. They were 383 in numbers and distributed in several subpopulations, i.e.:

a. Rumah Sakit Umum Daerah Prof. Dr. Aloei Saboe: 300 people.

b. Rumah Sakit Umum Daerah Otahana: 83 people.

2. Sample

Sampling technique was the proportional stratified random sampling, because:

a. Research population was a stratified population, but consisted of some subpopulations with imbalanced numbers of population.

b. The number of population group in the research had been unknown.

The number of sample was determined by using Slovin formulae:

Description:

$$
\mathrm{n}=\frac{\mathrm{N}}{1+\mathrm{Ne}^{2}}
$$

$\mathrm{n}=$ minimum size of sample/informant that would be taken

$\mathrm{N} \quad=$ population size

e $\quad=$ inefficiency percentage used due to sampling errors that could be still tolerated with the percentage limit of $1-10 \%$

Next, population group that could be used as subpopulations was based on status, position, profession, and job type or administration level. Here, the proportional allocation formulae by Al Rasyid could be used:

$$
n_{i}=\frac{N_{i}}{N} X n
$$

Description:

$n_{i}=$ the number of sample in the $\mathrm{i}^{\text {th }}$ subpopulation

$N_{i}=$ the number of members in the $\mathrm{i}^{\text {th }}$ subpopulation

$\mathrm{N}=$ the number of population

$\mathrm{n}=$ the number of sample/informants 
The number of population consisting of KONAS implementers in the government hospitals in Gorontalo according to the result of the calculation of the number of sample/informants in each subpopulation was:

Table 3.4 The Number of Population and Sample in Each Subpopulation of KONAS Implementers in Gorontalo

\begin{tabular}{|c|c|c|c|c|c|}
\hline \multirow{2}{*}{ NO. } & \multirow{2}{*}{ SUBPOPULATION } & \multicolumn{2}{|c|}{ RSUD PROF. DR. ALOEI SABOE } & \multicolumn{2}{|c|}{ RSUD OTANAHA } \\
\hline & & POPULATION & SAMPLE & POPULATION & SAMPLE \\
\hline 1 & Management/structure & 23 & 6 & 5 & 1 \\
\hline 2 & Medical workers & 54 & 13 & 6 & 2 \\
\hline 3 & Pharmaceutical workers & 15 & 4 & 4 & 1 \\
\hline 4 & Nursing workers & 208 & 50 & 68 & 16 \\
\hline & Total number & 300 & 73 & 83 & 20 \\
\hline
\end{tabular}

E. Data Collection Technique

Technical data collection suited to necessary data types and sources. Primary data were obtained by questionnaire, observation, and interview techniques; while secondary data were obtained by documentation and literary studies on various important publications or notes supporting the analysis and discussion of research results. The publications and notes should be related to KONAS implementation, apparatus work motivation, and health service quality in the government hospitals in Gorontalo. Research data were collected by using an instrument in forms of questionnaire structurally arranged. It consisted of some question items accompanied by the alternative answers, so that respondents might choose answers in accordance with the real condition. Level of variable measurement was ordinal; while the close answer category included five answer categories referring to a semantic difference scale that showed ideal and non-ideal value gradation, i.e. from 5, 4, 3, 2, and 1 (Mulyadi, 2016).

\section{F. Data Analysis Technique}

1. Data Analysis

Data were analyzed by using the PLS (Partial Least Square) method through several stages as mentioned by Ghozali and Latan (2015) that divided modelling stages and structural equation analysis into seven, namely: (1) Forming a structural model, (2) Forming a measurement model, (3) Creating a path graph, (4) Estimating a model, (5) Bootstrapping, a process replicating the number of sample to obtain a stable parameter estimation. In the process, testing/significance value were calculated based on the path estimation by using the t-test, (6) Evaluating a model. Models evaluated were outer and inner models, (7) Interpreting models by observing the p-value to make a decision of whether there was a direct or indirect effect of the independent variables. When the $p$-value $\geq 0.05$, $\mathrm{H}_{0}$ was accepted, or there was no significant influence of the independent variables. On the contrary, when the $\mathrm{p}$ value $<0.05, \mathrm{H}_{1}$ was accepted, or there was a significant influence of the independent variables.

\section{Hypothetical Test Design}

1. Determining tested hypotheses that were:

$\mathrm{H}_{0}=$ no positive influence

$\mathrm{H}_{1}=$ positive influence

2. Determining a testing tool that was the t-test.

3. Determining a decision regulation applied to the tested hypotheses that were:

When the $\mathrm{p}$-value $\geq 0.05, \mathrm{H}_{0}$ was accepted, $\mathrm{H}_{1}$ was rejected

When the $\mathrm{p}$-value $<0.05, \mathrm{H}_{1}$ was accepted, $\mathrm{H}_{0}$ was rejected

\section{a. Statistical Hypothesis}

Statistical hypotheses in the research were:

1) $\mathrm{H}_{0}$ : $\mathrm{p}$-value $\geq 0.05=$ There was no positive influence of KONAS implementation on health service quality in the government hospitals in Gorontalo.

$\mathrm{H}_{1}:$ p-value $<0.05=$ There was a positive influence of KONAS implementation on health service quality in the government hospitals in Gorontalo.

2) $\mathrm{H}_{0}$ : p-value $\geq 0.05=$ There was no positive influence of KONAS implementation on apparatus work motivation in the government hospitals in Gorontalo.

$\mathrm{H}_{1}:$ p-value $<0.05=$ There was a positive influence of KONAS implementation on health service quality in the government hospitals in Gorontalo.

3) $\mathrm{H}_{0}$ : $\mathrm{p}$-value $\geq 0.05=$ There was a positive influence of apparatus work motivation on health service quality in the government hospitals in Gorontalo.

$\mathrm{H}_{1}: \mathrm{p}$-value $<0.05=$ There was a positive influence of apparatus work motivation on health service quality in the government hospitals in Gorontalo

4) $\mathrm{H}_{0}$ : $\mathrm{p}$-value $\geq 0.05=$ There was no positive influence of KONAS implementation on health service quality mediated by apparatus work motivation in the government hospitals in Gorontalo.

$\mathrm{H}_{1}: \mathrm{p}$-value $<0.05=$ There was a positive influence of KONAS implementation on health service quality mediated by apparatus work motivation in the government hospitals in Gorontalo. 


\section{FINDINGS AND DISCUSSION}

\section{Descriptive Analysis of Research Data}

Research data were gathered by questionnaires distributed to 93 respondents in two government hospitals in Gorontalo. Each questionnaire contained questions of three research variables, i.e. the KONAS implementation variable as an exogenous variable with the $\xi$ symbol consisting of 27 statements, the apparatus work motivation variable as the first endogenous variable with the $\eta_{1}$ symbol consisting of 15 statements, and the health service quality variable as the second endogenous variable with the $\prod_{2}$ symbol consisting of 12 statements.

Respondent answers were given the lowest score 1 and the highest one 5: the very disagreeing answer (STS, Sangat Tidak Setuju) was given the score of 1, disagreeing answer (TS, Tidak Setuju) was given the score of 2, doubting answer (R, Ragu-ragu) was given the score of 3, agreeing answer (S, Setuju) was given the score of 4, and very agreeing answer (SS, Sangat Setuju) was given the score of 5. Value of each answer was recapitulated and the percentage was calculated to determine the quartile category of the total respondent answer score. Eventually there were four quartiles, namely:

- Quartile I : Low category with the minimum value of $0-<25 \%$.

- Quartile II : Inadequate category with the value of $25-<50 \%$.

- Quartile III : Adequate category with the value of $50-<75 \%$.

- Quartile IV : High category with the maximum value of 75-100\%.

Data description of respondent answer result for each variable is as follows:

a. Data Description of KONAS Implementation Variable ( $\xi)$

In general, KONAS implementation level belonged to the high category. In terms of the dimensions, all dimensions of KONAS implementation variable also belonged to the high category. Meanwhile, in the dimension of mentality, system, and networking approaches, the implementation levels were $88.05 \%, 88.67 \%$, and $86.24 \%$ respectively.

b. Data Description of Apparatus Work Motivation Variable (1)

Based on the data processing results of apparatus work motivation, in general, the level of apparatus work motivation was included in the high category. Each of the dimension was also included in the same category. The details are as follows: physiological needs by $36.38 \%$, safety needs by $84.66 \%$, love needs by $85.66 \%$, esteem needs by $86.09 \%$, and self-actualization needs by $90.97 \%$.

\section{c. Data Description of Health Service Quality Variable (1)}

In accordance with data processing results of work service quality variable, in general, the level of health service quality belonged to the high category. Percentage of each dimension was $86.83 \%, 88.61 \%$, and $86.19 \%$ for the dimensions of consumer/patient quality, professional quality, and management/health service funder quality respectively.

2. Results of Validity Test and Measurement Model Compatibility Reliability

a. Measurement Model Compatibility for the KONAS Implementation Variable ( $\xi)$

Test of measurement model compatibility for the KONAS implementation variable $(\xi)$ resulted a loading factor value; whereas from the first order of reflective indicator construct, we obtained the result indicating that all dimensions were valid.

Table 2.1 Test of Model Compatibility Validity for the KONAS Implementation Variable

\begin{tabular}{|l|l|c|c|c|}
\hline \multirow{4}{*}{$\begin{array}{c}\text { Variable } \\
\text { Dimension }\end{array}$} & $\begin{array}{c}\text { Convergent } \\
\text { Validity }\end{array}$ & $\begin{array}{c}\text { Discriminant } \\
\text { Validity }\end{array}$ & \multirow{2}{*}{ Description } \\
\cline { 2 - 5 } & Loading Factor & Cross Loading & \\
\hline \multirow{2}{*}{$\begin{array}{l}\text { KONAS } \\
\text { implementation }(\xi)\end{array}$} & Mentality approach & 0.869 & 0.587 & Valid \\
\cline { 2 - 5 } & System approach & 0.921 & 0.665 & Valid \\
\cline { 2 - 5 } & Networking approach & 0.884 & 0.678 & Valid \\
\hline
\end{tabular}

b. Measurement Model Compatibility for Health Service Quality (耳2)

Results of the model compatibility validity testing of each dimension for the health service quality variable proposed that all five dimensions forming the model were valid. 
Table 4.5 Test of Model Compatibility Validity for the Health Service Quality Variable (1/2)

\begin{tabular}{|l|l|c|c|c|}
\hline \multirow{2}{*}{ Variable } & \multirow{2}{*}{ Dimension } & $\begin{array}{c}\text { Convergent } \\
\text { Validity }\end{array}$ & $\begin{array}{c}\text { Discriminant } \\
\text { Validity }\end{array}$ & \multirow{2}{*}{ Description } \\
\cline { 3 - 5 } & Loading Factor & Cross Loading & Valid \\
\hline \multirow{3}{*}{$\begin{array}{l}\text { Health service quality } \\
\left(\Pi_{2}\right)\end{array}$} & Consumer quality & 0.863 & 0.787 & Valid \\
\cline { 2 - 5 } & $\begin{array}{l}\text { Professional } \\
\text { quality }\end{array}$ & 0.920 & 0.851 & Valid \\
\cline { 2 - 5 } & $\begin{array}{l}\text { Management } \\
\text { quality }\end{array}$ & 0.779 & 0.671 & Vald \\
\hline
\end{tabular}

Results of reliability testing (Cronbach's alpha and composite reliability) conducted by a test of model compatibility reliability for the health service quality variable $\left(\Pi_{2}\right)$ as revealed by Table 4.6 were good.

Table 4.6 Test of Model Compatibility Reliability for the Health Service Quality Variable $\left(\mathbf{\eta}_{2}\right)$

\begin{tabular}{|l|l|c|c|c|}
\hline \multirow{2}{*}{ Variable } & \multirow{2}{*}{ Dimension } & \multicolumn{2}{|c|}{ Reliability } & \multirow{2}{*}{ Description } \\
\cline { 3 - 5 } & & Cronbach's Alpha & Composite Reliability & Reliable \\
\hline \multirow{2}{*}{$\begin{array}{l}\text { Health } \\
\text { service } \\
\text { quality }\left(\eta_{2}\right)\end{array}$} & Consumer quality & 0.793 & 0.866 & Reliable \\
\cline { 2 - 5 } & Professional quality & 0.873 & 0.913 & Reliable \\
\cline { 2 - 5 }
\end{tabular}

3. Hypothesis Testing Results

a. KONAS Implementation Effects on Health Service Quality $\left[(\xi) \rightarrow\left(\mathbf{\eta}_{2}\right)\right]$

Evaluation of the inner model of KONAS implementation is stated in Table 3.1.

Table 3.1. Evaluation of Inner Model (Path Coefficients) of Each Dimension Forming the KONAS Implementation Variable

\begin{tabular}{|c|l|c|c|c|c|}
\hline No. & \multicolumn{1}{|c|}{$\begin{array}{c}\text { Dimensions Forming the KONAS } \\
\text { Implementation Variable }(\boldsymbol{\xi})\end{array}$} & $\begin{array}{c}\text { Coefficient } \\
\text { Value }\end{array}$ & $\begin{array}{c}\text { T- } \\
\text { statistic }\end{array}$ & $\begin{array}{c}\text { P- } \\
\text { value }\end{array}$ & Conclusion \\
\hline 1. & Mentality approach & 0.869 & 37.024 & 0.000 & Significant \\
\hline 2. & System approach & 0.921 & 46.578 & 0.000 & Significant \\
\hline 3. & Networking approach & 0.884 & 30.157 & 0.000 & Significant \\
\hline
\end{tabular}

Results of inner model evaluation in Table 3.1 proved that loading factors the first order of mentality, system, and networking approach constructs was significant at $5 \%$, suggested by the t-statistic value that was higher than the t-table value 1.96, clarifying that KONAS implementation construct was formed by three dimensions namely mentality, system, and networking approaches by $86.9 \%, 92.1 \%$, and $88.4 \%$ respectively.

Testing results for loading factors in the second order of KONAS implementation can be observed in Table 3.2. The loading factors were significant at $5 \%$, as the $t$-statistic value was higher than the t-table value 1.96 that was 2.613. Additionally, the p-value was 0.009 and existed in the significance p-value of $<0.05$, although with a small influence coefficient value that was $30.9 \%$.

Table 3.2 Inner Model (Total Effects) Evaluation of KONAS Implementation ( $\xi$ )

\begin{tabular}{|l|c|c|c|c|}
\hline Effect Path $(\rightarrow)$ & Coefficient Value & T-statistic & P-value & Conclusion \\
\hline $\begin{array}{l}\text { KONAS implementation } \rightarrow \text { health service } \\
\text { quality }\left[(\xi) \rightarrow\left(\Pi_{2}\right)\right]\end{array}$ & 0.309 & 2.613 & 0.009 & Significant \\
\hline
\end{tabular}

In accordance with the $\mathrm{p}$-value $<0.05, \mathrm{H}_{0}$ was rejected; while $\mathrm{H}_{1}$ was accepted, or there was a significant effect at the significance level of $5 \%$ of KONAS implementation on health service quality in the government hospitals of Gorontalo.

b. KONAS Implementation Effects on Apparatus Work Motivation $\left[(\xi) \rightarrow\left(\eta_{1}\right)\right]$

Results of inner model evaluation in Table 4.9 clarified that loading factors in the first order of physiological, safety, love, esteem, and self-actualization needs constructs was significant at the level of 5\%, confirming by the t-statistic value higher than the t-table value 1.96 and the p-value of each needs construct that was 0.000 lower than the $\mathrm{p}$-value $<0.05$. It conveyed that the construct of apparatus work motivation variable formed by five dimensions also had the same effect coefficients that were $76.5 \%, 71.1 \%, 71.2 \%, 77.6 \%$, and $79.0 \%$ for the physiological, safety, love, esteem, and self-actualization needs respectively. 
Table 3.3 Inner Model (Path Coefficients) Evaluation of Each Dimension Forming the Apparatus Work Motivation Variable (1)

\begin{tabular}{|c|l|c|c|c|c|}
\hline No. & $\begin{array}{l}\text { Dimensions Forming the Apparatus Work } \\
\text { Motivation Variable }\end{array}$ & $\begin{array}{c}\text { Coefficient } \\
\text { Value }\end{array}$ & $\begin{array}{l}\text { T- } \\
\text { statistic }\end{array}$ & $\begin{array}{l}\text { P- } \\
\text { value }\end{array}$ & Conclusion \\
\hline 1 & Physiological needs & 0.765 & 14.174 & 0.000 & Significant \\
\hline 2 & Safety needs & 0.711 & 13.183 & 0.000 & Significant \\
\hline 3 & Love needs & 0.712 & 9.083 & 0.000 & Significant \\
\hline 4 & Esteem needs & 0.776 & 16.102 & 0.000 & Significant \\
\hline 5 & Self-actualization needs & 0.790 & 22.392 & 0.000 & Significant \\
\hline
\end{tabular}

Moreover, hypothesis test results performed to investigate KONAS implementation effects on apparatus work motivation are shown in Table 4.10. Results of inner model implementation in Table 4.10 conveyed that loading factors in the second order of KONAS implementation on apparatus work motivation were significant at the level of $5 \%$, as the t-statistic value of the second order was 11.624 and had a value higher than the $t$-table value that was 1.96. Moreover, the p-value 0.000 was lower than the p-value 0.05 ; while the effect coefficient value was $70.6 \%$. Table 3.4 Inner Model (Path Coefficient) Evaluation of Apparatus Work Motivation Variable

\begin{tabular}{|l|c|c|c|c|}
\hline \multicolumn{1}{|c|}{ Relationship Path } & $\begin{array}{c}\text { Coefficient } \\
\text { Value }\end{array}$ & $\begin{array}{c}\text { T- } \\
\text { statistic }\end{array}$ & $\begin{array}{c}\text { P- } \\
\text { value }\end{array}$ & Conclusion \\
\hline $\begin{array}{l}\text { KONAS implementation }(\xi) \rightarrow \text { apparatus work } \\
\text { motivation }\left(\eta_{1}\right)\end{array}$ & 0.706 & 11.624 & 0.000 & Significant \\
\hline
\end{tabular}

Referring to data and result of hypothesis test, we might conclude that $\mathrm{H}_{1}$ was accepted; while $\mathrm{H}_{0}$ was rejected, or there was a significant effect at the level of 5\% of KONAS implementation on apparatus work motivation in the government hospitals in Gorontalo.

c. Effects of Apparatus Work Motivation on Health Service Quality $\left[\left(\eta_{1}\right) \rightarrow\left(\eta_{2}\right)\right]$

Results of inner model evaluation declared that loading factors in the first construct order of dimensions forming the health service quality variable were significant at the level of 5\%, because the t-statistic value of the first order had a value higher than the t-table value 1.96 and the $p$-value of each was 0.000 lower than the p-value that was 0.05 .

Table 3.5 Inner Model (Path Coefficient) Evaluation of Each Dimension Forming the Health Service Quality Variable ( $\left.\mathbf{\eta}_{2}\right)$

\begin{tabular}{|c|l|c|c|c|c|}
\hline No. & $\begin{array}{l}\text { Dimensions Forming the Health } \\
\text { Service Quality Variable }\end{array}$ & $\begin{array}{c}\text { Coefficient } \\
\text { Value }\end{array}$ & T-statistic & P-value & Conclusion \\
\hline 1 & Consumer quality & 0.863 & 27.442 & 0.000 & Significant \\
\hline 2 & Professional quality & 0.920 & 55.765 & 0.000 & Significant \\
\hline 3 & Management/funder quality & 0.779 & 18.783 & 0.000 & Significant \\
\hline
\end{tabular}

Results of inner model evaluation defined that loading factors in the second order of apparatus work motivation on health service quality were significant at the level of $5 \%$, since the t-statistic value of the second order that was 4.478 was higher than the t-table value that was 1.96 . Meanwhile, the p-value that was 0.000 was lower than the significance level of p-value $<0.05$; whereas the effect coefficient value was $52.3 \%$.

Table 3.6 Inner Model (Path Coefficient) Evaluation of Apparatus Work Motivation Variable (П1) on Health Service Quality (1)

\begin{tabular}{|l|c|c|c|c|}
\hline Relationship Path & Coefficient Value & T-statistic & P-value & Conclusion \\
\hline $\begin{array}{l}\text { Apparatus work motivation }\left(\Pi_{1}\right) \rightarrow \text { health } \\
\text { service quality }\left(\Pi_{2}\right)\end{array}$ & 0.523 & 4.478 & 0.000 & Significant \\
\hline
\end{tabular}

According to the data and result of hypothesis test, H1 was accepted; while H0 was rejected, or there was a significant effect of apparatus work motivation oh health service quality in the government hospitals in Gorontalo.

d. KONAS Implementation Effects Mediated by Apparatus Work Motivation on Health Service Quality $\left[(\xi) \rightarrow\left(\eta_{1}\right) \rightarrow\left(\eta_{2}\right)\right]$

The first path of KONAS implementation to apparatus work motivation was significant at the level of 5\%, as the $\mathrm{t}$-statistic value 11.624 was higher than the t-table value 1.96 . Additionally, the p-value 0.000 was lower than the significance level of $\mathrm{p}$-value $<0.05$; while the effect coefficient value was $70.6 \%$. Meanwhile, the second relationship path of apparatus work motivation to health service quality was also significant at the level of $5 \%$, because the t-statistic value 4.478 was higher than $\mathrm{t}$-table value 1.96 ; while the $\mathrm{p}$-value 0.000 was lower the significance level of $p$-value $<0.05$ and the effect coefficient value was only $52.3 \%$. 
Table 3.7 Inner Model (Path Coefficient) Evaluation of KONAS Implementation Variable Mediated by Apparatus Work Motivation on Health Service Quality

\begin{tabular}{|c|l|c|c|c|c|}
\hline No. & \multicolumn{1}{|c|}{ Relationship Path } & $\begin{array}{c}\text { Coefficient } \\
\text { Value }\end{array}$ & $\begin{array}{c}\text { T- } \\
\text { statistic }\end{array}$ & $\begin{array}{c}\text { P- } \\
\text { value }\end{array}$ & Conclusion \\
\hline 1 & $\begin{array}{l}\text { KONAS implementation } \rightarrow \text { health service } \\
\text { quality }\left[(\xi) \rightarrow\left(\eta_{2}\right)\right]\end{array}$ & 0.309 & 2.613 & 0.009 & Significant \\
\hline 2 & $\begin{array}{l}\text { KONAS implementation } \rightarrow \text { apparatus work } \\
\text { motivation }\left[(\xi) \rightarrow\left(\eta_{1}\right)\right]\end{array}$ & 0.706 & 11.624 & 0.000 & Significant \\
\hline 3 & $\begin{array}{l}\text { Apparatus work motivation } \rightarrow \text { health service } \\
\text { quality }\left[\left(\eta_{1}\right) \rightarrow\left(\eta_{2}\right)\right]\end{array}$ & 0.523 & 4.478 & 0.000 & Significant \\
\hline 4 & $\begin{array}{l}\text { KONAS implementation } \rightarrow \text { apparatus work } \\
\text { motivation } \rightarrow \text { health service quality }\left[(\xi) \rightarrow\left(\eta_{1}\right)\right. \\
\left.\rightarrow\left(\eta_{2}\right)\right]\end{array}$ & 0.615 & 8.051 & 0.000 & Significant \\
\hline
\end{tabular}

Results of hypothesis test with the inner model evaluation on the second relationship path also affected results of the inner model evaluation of KONAS implementation mediated by apparatus work motivation on health service quality. Moreover, t-statistic value was 8.051 and significant at the level of 5\%, because it was higher than the ttable value 1.96. P-value 0.000 was below the significance level of $\mathrm{p}$-value $<0.05$ with the effect coefficient value that was $61.5 \%$.

Based on the data and results of hypothesis test, $\mathrm{H}_{1}$ was accepted; while $\mathrm{H}_{0}$ was rejected, or there was a significant effect of KONAS implementation mediated by apparatus work motivation on health service quality in the government hospitals in Gorontalo.

4. Prototype of the New Models of KONAS Implementation, Apparatus Work Motivation, and Health Service Quality

Research results of KONAS implementation and apparatus work motivation effects on health service quality in the government hospitals in Gorontalo described that even though KONAS implementation positively influenced health service quality in the government hospitals in Gorontalo, the influences were only 30.09\%, requiring other variables that might confirm them. MSN approach model used in the dimension arranging the KONAS implementation variable to investigate the effect on health service quality in the government hospitals in Gorontalo required a new model to produce a stronger effect on the service quality.

Another variable that had been tested was apparatus work motivation. Results of hypothesis testing indicated that KONAS implementation gave a stronger effect to health service quality in the government hospitals in Gorontalo when mediated by apparatus work motivation. The effect could be identified when we compared it to when it was only the KONAS implementation that was directly used. Therefore, we required a development model that used a dimension forming the apparatus work motivation variable as an accelerator in the MSN approach model to accelerate and improve KONAS implementation effects on health service quality.

Results of interview with respondents that was conducted to confirm quantitative data and and had been elaborated in Findings and Discussion explained that commitments of all health apparatuses providing services in hospitals was one of the aspects determining improved health service facility in the government hospitals in Gorontalo. Therefore, optimization of health service quality through KONAS implementation and apparatus work motivation should be enforced by agreeable variables that united all stakeholders in hospitals. Moreover, another variable that should be added in the offered new prototype model was the commitment variable as a solution of issues due to the results of in-depth interview with respondents, either with KONAS implementers or patients as the health service acceptors in hospitals.

Commitment was an agreement as a bond of all stakeholders to realize their vision, mission, goals, and stipulated policies including KONAS that should be implemented in health services in hospitals. Integration among KONAS implementation, work motivation, and apparatus commitment would gave acceleration to improve health service quality in hospitals.

Based on Kamus Besar Bahasa Indonesia, acceleration was a process of accelerating, increasing acceleration, speed, speed change rate. Moreover, in accordance with Wikipedia Bahasa Indonesia, acceleration was changed speed in a certain time unit. The intended acceleration was an acceleration process to increase health service quality by Triple Helix integration between public policy implementation, work motivation, and apparatus commitment. Prototype of the development model is illustrated in Figure 4.12. 
Figure 4.1 Triple Helix of Public Policy Implementation-Motivation-Commitment to Optimize Health Service Quality

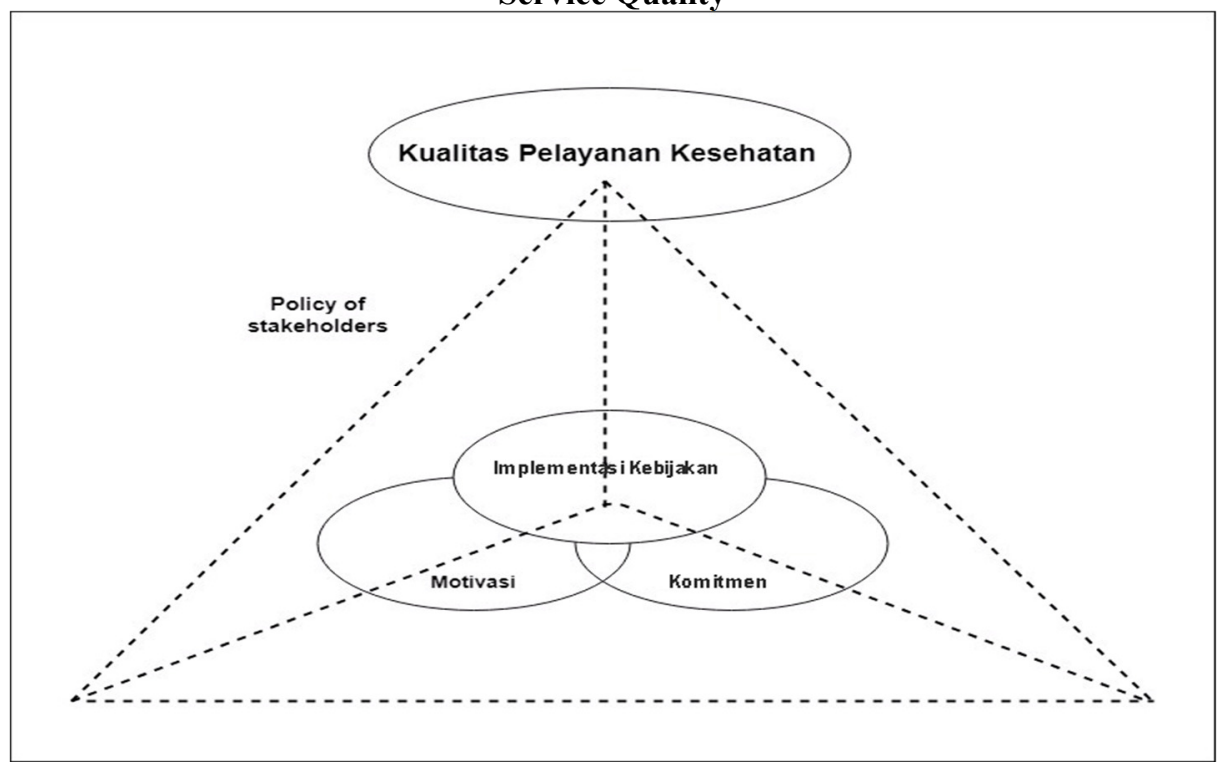

Figure 4.1 gave us a new paradigm that to optimize health service facility, public policy implementation should be integrated to work motivation and commitments of all apparatuses involving in health services in hospitals. Models of the theories of public policy implementation, work motivation, commitment, and health service quality were made into a formulae called the HSQ-MK (Health Services Quality-Muhammad Kasim) model.

Figure 4.1 can be elaborated to provide a clearer understanding as follows:

\section{Public Policy Implementation}

The public policy implementation referred to the MSN-approach model. MSN-approach was defined as an approach that collaborated roles and existences of three health policy stakeholders, i.e. regulator (the government), provider (health service provider, either the government or private), and the society as the user and service receiver. The approach was realized into mentality, system, and networking approach dimensions. MSN-approach dimension was as follows:

a) Mentality consisting of:

1) Attitude: Attitudes that should be had by health apparatuses implementing policies were respectful, honest, and discipline in implementing health service tasks.

2) Behavior: Health apparatuses should act by referring to the value and ethical code, be consistent to their value and faith, and have integrity and courage to take actions in health services.

3) Responsibility: Responsibility was an ability and willingness to complete a task in accordance with service procedures and standards. Besides, health apparatuses should be in time and willing to take risks that might be appear during their service.

b) System consisting of:

1) Regulation system: Regulation formed for patient and social importance. Health apparatuses always improved productivity and service quality by enhancing their competence and encouraging the society and transparency in health services.

2) Cultural value system: Health apparatuses upheld and respected local wisdoms believed and developing in the society, kinship, and mutual cooperation to solve health service issues.

3) Structural system and organization system: A combination between structure and organization function to implement policies supported by cooperation relationship and mutual dependence among the government, private parties, and society and harmonic relationship among medical committee, pharmaceutical and therapeutic committee, nursing committee, and other health worker committees that played an important role in health services in hospitals.

c) Networking consisting of:

1) Strategic partnership: A relationship established according to equality spirit, openness, and mutual cooperation to realize social importance in health services.

2) Synergy: Health apparatuses should establish a relationship and ensure the internal cooperation relationship to stay in a productive institutional structure and harmonic partnership by accommodating the stakeholders to provide qualified health services.

3) Symbiosis of mutualism: A relationship among various different parties that gave benefits to each other 
and supported hospital policies in terms of health service provision.

\section{Apparatus Work Motivation}

Apparatus work motivation was a concept referring to the needs theory by Maslow consisting of five types of needs, i.e. physiological needs, safety needs, love needs, esteem needs, and self-actualization needs. Dimensions of apparatus work motivation were:

a. Physiological needs were physical, material needs needed in the implementation of health facilities in hospitals, namely a) representative and comfortable workroom provision, b) necessary work facility provision, and c) efficient and effective infrastructure provision.

b. Safety needs were needs of safety, either physical or mental against fear of the risks of work conducted in hospitals that were a) Safety guarantee of work environment: Health apparatuses felt safe working in hospitals, as there were securities working for 24 hours a day, b) Safety supports to implement works: Health apparatuses did not worry about safety risks of their works, either physical or mental, and c) Protection against working risks: Health apparatuses should be protected against work risks by hospitals including risks of malpractices. In this dimension, insurance; such as compensation for malpractices should be developed to give a safe feeling. The insurance might be provided by cooperation with insurance companies facilitated by the hospital management. Insurance premium could become the responsibility of both health apparatus and hospital. By this insurance, health apparatus would feel safe while implementing their tasks. When any risk happened, compensation demand due to malpractice might become the responsibility of all parties.

c. Love needs were admission and appreciation of works and services done that were: a) Incentive: Health apparatuses should be satisfied by salary and incentive given by hospitals. Incentive that might be developed in government hospitals was incentive for obedience to implement hospitals regulations. Because by consistent and continuant obedience in regulation, drug cost might be suppressed, resulting in efficient hospital budget use. Such efficiency might be used as an incentive for activities to enhance health service quality in hospitals; b) Leader appreciation: Health apparatuses should be appreciated by the head of hospital when performing and achieving well. Hospital management should regularly appreciate their best and achieved health apparatuses that could provide health services in hospitals. Furthermore, such action might motivate other health apparatuses; and c) Related institutional appreciation: The government of Gorontalo and related institutions paid attention and appreciation to hospitals to improve service quality.

d. Esteem needs were an opportunity to cooperate and create a group that could help and give services to each other that were: a) Relationship among apparatuses: Health apparatuses did not find any difficulties to do duties related to other apparatuses in hospitals; b) Supports from other apparatuses: Partners should always give supports to their partners duties; and c) Relationship between apparatuses and related work units: Their works might be smoothly performed due to a good relationship with other apparatuses of other work units.

e. Self-actualization needs were an opportunity to actualize health apparatuses' self and professional skill to give qualified health services, i.e. a) Apparatus identity actualization: Health apparatuses should be proud of their identity and profession, b) Apparatus professionalism actualization: Health apparatuses should actualize their professional skill and provide good health services, and c) Apparatus accountability actualization: Health apparatuses should be responsible of their duties from either their profession or God.

\section{Commitment}

Kamus Besar Bahasa Indonesia (KBBI) defined commitment as an agreement to do something, or contract. The word originally came from Latin, commiter that meant uniting, performing, combining, and trusting. Therefore, commitment was a loyal and responsible attitude of individuals to something, either to themselves, others, organization, or a certain matter.

Meanwhile, Greenberg (2003) described commitment as a willingness of officers or apparatuses to favor a certain organization and its goals and intend to maintain membership in it. Moreover, Steers and Porter (1983) argued that commitment was a situation where individuals were tied by their actions, creating beliefs supporting their activities and involvement.

As one of the regional working units, government hospitals should establish a commitment among all of their apparatuses. Organization commitment in a hospital could be defined as an attitude conducted by individuals to identify themselves towards goals and expectations of hospitals where they worked. Additionally, they should also maintain their consistency to realize the hospital goals. Meanwhile, commitment would emerge in each health apparatus due to their responsibility of task and profession. Several people committed, as they loved their job; while others committed because of fear of losing something when they did not conduct their duties. Therefore, health apparatuses would consistently implement KONAS as a policy that should be done and give good health services.

Hospital visions, missions, and goals would be able to be realized by a strong commitment of all hospital stakeholders. Therefore, the government hospital management should concern of characteristics that affected commitments in hospitals, i.e.:

1. Individual characteristics consisting of two factors, namely demographic and dispositional factors. 
Demographic factor covered gender, age, marital status, education level, and working period in hospitals. Moreover, dispositional factor included personality and value of health apparatuses. The second factor had a stronger relationship with working commitment, due to different experiences owned by health apparatuses. Individual characteristics of health apparatuses in hospitals varied, since they came from diverse health education background, from high school, diploma, and postgraduate education. Such diversity generated various professions and created both demographic and dispositional of health apparatuses in hospitals.

2. Organization characteristics consisting of hospital organization structure, policy design in hospitals, and hospital socialization design. Hospital organization structure was different from structures of other regional working units, as hospitals constituted a public service unit consisting of various education background and professions and using technological and expensive equipment. Besides, hospitals also had to often emergency situations while providing health services, so that their policy should be widely socialized in order to be able to be well implemented.

3. Experiences in doing tasks consisting of the satisfaction and motivation of health apparatuses while they were working in the government hospitals, their roles in hospitals, and their relationship with hospital management or head. Different work period and professions caused different experiences, motivation, and work satisfaction of health apparatuses, requiring a strong commitment of all health apparatuses to give optimum health services based on great ethics and Hippocratic oath to achieve goals that had been stipulated in hospital visions, missions, and goals.

Integration of public policy implementation, work motivation, and apparatus commitment would accelerate the increase of health service quality in hospitals. Therefore, commitment variables were arranged by three dimentions, as referred by Allen and Meyer (1991) that were:

1. Affective commitment was a psychological attachment to hospitals based on individual feelings towards the hospitals. The commitment referred to emotional attachment of health apparatuses to hospitals. Mostly functional workers of various professions, health apparatuses were willing to work in hospitals, as they agreed with the goals and values of the hospitals. With an affective commitment level, the health apparatuses wanted to stay in the hospitals, because they supported the hospital goals and are willing to help to achieve goals stipulated by the head of the hospitals. Affective commitment would exist when health apparatuses wanted to be a part of organization due to emotional attachment or had the same value as the hospital vision, mission, and aims.

2. Continuant commitment was individual willingness as health apparatuses to keep working in a hospital, because they were unable to find other works or got a certain reward. The commitment referred to their desire to keep working in the hospital because of calculation or analysis on profits and loss of working there. The longer the health apparatuses worked in the hospital, the more the fear of the loss of what they had been invented while working was.

3. Normative commitment appeared due to the feelings of health apparatuses. They were obliged to keep working in hospitals because of others' oppression. Those with a high normative commitment level would greatly concern of what people said if they left the hospitals. They did not want to disappoint their employers and worried if their partners gave them a bad perception due to their resignation. In other words, the commitment emerged because of profession value of the health apparatuses. They kept working in hospital due to awareness that commitment to hospitals was their obligation as a form of dedication.

\section{CONCLUSION}

According to the findings and discussion on the effects of KONAS implementation and apparatus work motivation on health service quality in the government hospitals in Gorontalo, we summarized several conclusions as follows:

1. There was a positive, significant effect of KONAS implementation at the level of $5 \%$ on health service quality with the effect coefficient of 0.309 . It clarified that although significant, it did not strongly affect health service quality in the government hospitals in Gorontalo, and hence required other variables for the implementation.

2. There was a positive, significant effect of KONAS implementation at the level of 5\% on apparatus work motivation with the effect coefficient of 0.706 . It confirmed the implementation strongly affected apparatus work motivation in the government hospitals in Gorontalo.

3. There was a positive, significant effect of apparatus work motivation at the level of $5 \%$ on health service quality with the effect coefficient of 0.5023 , conveying that apparatus work motivation strongly affected health service quality in the government hospitals in Gorontalo.

4. There was a positive, significant effect of KONAS implementation mediated by apparatus work motivation at the level of $5 \%$ on health service quality with the effect coefficient of 0.615 , declaring to give an effect to health service quality in the government hospitals in Gorontalo, the implementation should be mediated by apparatus work motivation.

5. Integration of public policy, work motivation, and apparatus commitment generated a new prototype model of public policy implementation as the HSQ-MK model. 


\section{REFERENCES}

Abdussamad, Z., 2016, Kompetensi Aparat dalam Pelayanan Publik, Deepublishing (Grup Penerbit CV. Budi Utama), Yogyakarta.

Adisasmito, W., 2009. System Manajemen Lingkungan Rumah Sakit, Rajawali Press, Jakarta.

Alamsyah, D., 2011. Manajemen Pelayanan Kesehatan, Nuhamedika, Yogyakarta.

Ali, E M, 2013, Kepemimpinan Integratif dalam Konteks Good Governance, PT. Multi Cerdas Publishing, Jakarta.

Anderson, J. A. 1979, Public Policy Making. $3^{\text {rd }}$ ed. Miffin Company. Houghton USA.

Azwar, A., 1996, Menjaga Mutu Pelayanan Kesehatan, Sinar Harapan, Jakarta.

Azwar, A., 2011. Pengantar Administrasi Kesehatan. $3^{\text {rd }}$ ed, PT Binarupa Aksara, Jakarta.

Bryson, J. M., 2004, Strategic Planning for Public and Nonprofit Orgnazations, $3^{\text {rd }}$ ed., Jossey - Bass A Wiley Imprint, San Fransisco.

Cahyani, N. et al., (2012). Kajian tentang Tingkat Efisiensi Pelayanan Kesehatan Rumah Sakit Umum Pemerintah Kabupaten/kota di Jawa Timur Menggunakan Metode PCA-DEA, Jurnal Sains dan Seni ITS Volume 1 No. 1 (September 2012) ISSN: 2301-928X. Surabaya.

Daris, A. 2008. Himpunan Peraturan dan Perundang-undangan Kefarmasian. PT Isfi Penerbitan, Jakarta.

Defrika, R., 2015. Jurnal Ilmu Administrasi Negara, Volume 13, No. 2, Januari 2015: 85-90.

Ministry of Health of the Republic of Indonesia, 2004. The Law of the Republic of Indonesia Number 29 Year 2004 on Medical Practice. Ministry of Health of the Republic of Indonesia, Jakarta

Ministry of Health of the Republic of Indonesia, 2009. National Health System. Ministry of Health of the Republic of Indonesia, Jakarta.

Health Office of Gorontalo, 2014. Profil Kesehatan Kota Gorontalo 2013. Gorontalo.

Health Office of Gorontalo, 2015. Profil Kesehatan Kota Gorontalo 2014. Gorontalo.

Health Office of Gorontalo, 2016. Profil Kesehatan Kota Gorontalo 2015. Gorontalo.

Dunn, 2013. Public Policy Analysis: An Introduction, Prentce Hall, Inc: Englewood Cliffs, translated by Samudro Wibawa et al., $2^{\text {nd }}$ ed, Gadjah Mada University Press, Yogyakarta.

Dwiyanto, A. (ed). 2008, Mewujudkan Good Governance Melalui Pelayanan Publik. Gadjah Mada University Press, Yogyakarta.

Dwiyanto, A. 2012, Manajemen Pelayanan Publik: Peduli, dan Kolaboratif. $2^{\text {nd }}$ ed, Gadjah Mada University Press, Yogyakarta.

Dwiyanto, A. 2015, Reformasi Birokrasi Kontekstual. Gadjah Mada University Press, Yogyakarta.

Dye, 2008. Understanding Public Policy, Pearson Education; Upper Saddle River: Newjersey.

Evans, R.G., 1984. Strained Mercy: the Economic of Canadian Health Care, Butterworths, Toronto, Canada.

Firda, F., 2013. Administrative Responsibility: Studi Deskriptif Perilaku Kerja Pegawai pada Pelayanan Publik Perspektif Adminstrative Responsibility di Dinas Kependudukan dan Catatan Sipil Kota Surabaya. Jurnal Kebijakan dan Manajemen Publik, Volume 1, No. 1, January 2013. Universitas Airlangga Surabaya.

Gasperz, V. 2005. Total Quality Management. Jakarta: PT Gramedia Pustaka Utama.

Gozali, I., and Lathan, H., 2015. Partial Least Squares, Konsep, Teknik, dan Aplikasi Menggunakan Program Smart PLS 3.0 (untuk Penelitian Empiris), Semarang: Badan Penerbit Universitas Negeri Diponegoro.

Grindle and Merilee S. 1980. Politics and Policy Implementation in the Third World. New Jersey: Princeton University Press.

Handoko, H., 2001. Manajemen Personalia dan Sumber Daya Manusia. $2^{\text {nd }}$ ed. BPFE: Yogyakarta.

Hartini, YS. and Sulasmono, 2010, Praktik Kefarmasian: Ulasan Peraturan tentang Bidang Pekerjaan Apoteker, Penerbit Universitas Sanata Dharma, Yogyakarta.

Hasibuan, MSP. 2008. Manajemen Sumber Daya Manusia, revised ed. Bumi Aksara: Jakarta.

Himawan, R., 2014, Menjamin Akses terhadap Sediaan Farmasi dan Alat Kesehatan untuk Sistem Kesehatan yang Lebih Baik, Buletin INFARKES Edisi III.

Jones, translated by Ricky Istmato 1991, An Introduction to Study of Public Policy, $1^{\text {st }}$ ed, CV Rajawali.

Cooper, L. Terry. 1998. The Responsible Administrator: an Approach to Ethics for the Adminstrative Role. United States: Jossey Bay.

Kadji, Y., 2012, Teori tentang Motivasi, Jurnal Inovasi Volume 9, No.1, March 2012.

Kadji, Y., 2015. Formulasi dan Implementasi Kebijakan Publik: Kepemimpinan dan Perilaku Birokrasi dalam Fakta Realitas, UNG Press, Gorontalo.

Kadji, Y., 2016. Metode Penelitian Ilmu Administrasi, Deepublishing (Grup Penerbit CV. Budi Utama), Yogyakarta.

Kalbers L., P and Timhoty J. Fogarty. 1995. "Professionalism and Its Consequences: a Study of Internal Auditors". A Journal of Practice and Theory. Spring. Vol. 14. No. 1. pp. 64-85 http://gateway.proquest.com.

Keban, 2014, Enam Dimensi Strategis Administrasi Publik Konsep, Teori, dan Isu, $3^{\text {rd }}$ ed., Gava Media, Yogyakarta.

Ministry of the Health of the Republic of Indonesia, 2011, Development Plan for Health Workers in 2011-2025, 
Division of Human Resource Development of the Ministry of the Health of the Republic of Indonesia, Jakarta.

Ministry of the Health of the Republic of Indonesia, 2016, Regulation of the Ministry of Health of the Republic of Indonesia Number 72 Year 2016 on Pharmaceutical Service Standards in Hospital. Jakarta.

Ministry of the Health of the Republic of Indonesia, 2016, Regulation of the Ministry of Health of the Republic of Indonesia Number HK.02.02/MENKES/636/2016 on National Formularium. Jakarta.

Kotler, P., 2002, Marketing Management, $10^{\text {th }}$ ed., translated by Hendra Teguh et al., Pearson Education Asia Pte, Ltd, Jakarta.

Makmur, H, 2015, Filsafat Administrasi, Bumi Aksara, Jakarta.

Mazmanian. D. A. and Paul A. S., (2003), Implementation and Public Policy, Scott, Foresman and Company, London.

Mills, A. et al. 1991, Health System Decentralization: Concepts, Issue, Country Experience, translated by Trisnantoro, L. Gadjah Mada University Press, Yogyakarta.

Moenir. 2008. Manajemen Pelayanan Umum di Indonesia. PT Bumi Aksara. Jakarta.

Mulyadi, M., 2016. Metode Penelitian Praktis, Kuantitatif, dan Kualitatif. Jakarta: Publica Press.

Nasution, E., 2014, Jurnal Al-Bayan, vol. 20, no. 29, January-June 2014.

Nasution, MN. 2005. Manajemen Pelayanan Terpadu, $2^{\text {nd }}$ ed. Ghalia Indonesia, Jakarta.

Niode, A, 2017, Hasil Pelayanan Publik, Kota Gorontalo Terburuk Se-Indonesia, Harian Gorontalo, Wednesday, 7 January 2017.

Notoadmojo, S., 2007, Kesehatan Masyarakat: Ilmu dan Seni, Rineke Cipta, Jakarta.

Nugroho, R. 2014, Public Policy: Teori, Manajemen, Dinamika, Analisis, Konvergensi, dan Kimia Kebijakan. $5^{\text {th }}$ ed., PT. Elex Media Komputindo Kelompok Gramedia, Jakarta.

Pasolong, H., 2008. Kepemimpinan Birokrasi. Alfabeta, Bandung.

Poernomo, B. 2002, Hukum Kesehatan, Aditya Media, Yogyakarta.

Purwanto, EA. and Sulistyastuti, D. R. 2012. Implementasi Kebijakan Publik: Konsep dan Aplikasinya di Indonesia. Gava Media, Yogyakarta.

Purwanto, S, 2016, Statistika untuk Ekonomi dan Keuangan Modern, $3^{\text {rd }}$ ed., Salemba Empat, Jakarta.

Rakhmat, 2009, Teori Administrasi dan Manajemen Publik, Pustaka Arif, Jakarta.

Robbins, S. P and Coulter, M., 1999, Management, $6^{\text {th }}$ ed., Prantice Hall International, Inc, New Jersey.

Robbins, SP. 2001. Perilaku Organisasi: Konsep, Kontroversi, dan Aplikasi, translated by Dr. Hadyana Pujaatmaka. Pearson Education Pte. Ltd and PT. Perenhallindo. Jakarta.

Robert, 1996. Pelayanan Publik, PT Gramedia Pustaka Utama, Jakarta.

Rusdiana, N. et al. 2015. Kualitas Pelayanan Farmasi Berdasarkan Waktu Penyelesaian Resep di Rumah Sakit, Jurnal Pharmaçiana, Vol. 5, No. 2, 2015: 169-176.

Saranga, E., 2000. Analisis Efisiensi Proses Layananan Kualitas Pelayanan Rumah Sakit: Penerapan Data Envelopment Analysis (DEA) dan Model Servqual (GAP 5). (Thesis). Universitas Gadjah Mada, Yogyakarta.

Siagian, P.S., 2003. Teori dan Praktek Kepemimpinan. Rineka Cipta. Jakarta.

Sinambela, L.P, 2010, Reformasi Pelayanan Publik: Teori, Kebijakan, dan Implementasi. Bumi Aksara, Jakarta.

Sinamo, J., 2005, Delapan Etos Kerja Profesional, Penerbit Institut Darma Mahardika, Jakarta.

Siregar, C. J. P, 2004, Farmasi Rumah Sakit: Teori dan Penerapan, EGC Penerbit Buku Kedokteran, Jakarta.

Sudjana, 2005, Metode Statistika, PT. Tarsito, Bandung.

Sulastomo, 2000, Manajemen Kesehatan, PT. Gramedia Pustaka Utama, Jakarta.

Suharto, E. 2014. Analisis Kebijakan Publik, Panduan Praktis Mengkaji Masalah dan Kebijakan Sosial, Alfabeta, Bandung.

Spencer, L., M.Jr. dan Signe M.S., 1993. Competence at Work. New York: John Wiley \& Sons, Inc

Tachjan, 2006. Implementasi Kebijakan Publik, AIPI Bandung - Puslit KP2W Lemlit UNPAD Bandung.

Tahir, A. 2014, Kebijakan Publik dan Transparansi Penyelenggaraan Pemerintah Daerah. Alfabeta, Bandung.

Tanner, A. E., et al., 2015, Evaluasi Pelaksanaan Pelayanan Resep Obat Generik Pada Pasien BPJS Rawat Jalan di RSUP Prof. Dr. R.D. Kandou Manado Periode Januari-Juni 2014, Jurnal Ilmiah Pharmacon, Farmasi Unsrat, Manado.

Thabrany, 2000, Asuransi Kesehatan dan Akses Pelayanan Kesehatan. Majalah Kedokteran Indonesia, 50 (6): 282-289.

Thantawi As, SE, MS, 2009, Pengantar Manajemen, $1^{\text {st }}$ ed., Biro Penerbitan Fak. Ekonomi Universitas Brawijaya, Malang.

Tjiptono, F. and Diana, A. 2003, Total Quality Management, Penerbit Andi Offset, Yogyakarta.

Tjiptono, F. 2003, Total Quality Service, Penerbit Andi Offset, Yogyakarta.

Uno, H. B., 2010. Teori Motivasi dan Pengukurannya, Bumi Aksar, Jakarta.

Widodo, J. 2011. Membangun Birokrasi Berbasis Kinerja. Bayumedia Publishing. Malang.

Winardi, 1992. Manajemen Prilaku Organisasi. PT Citra Aditya Bakti, Bandung.

Zwell, M., 2005. Creating a Culture of Competence. John Wiley \& Sons, Inc. New York. 